\title{
Danielių, laikomų aptvare, įtaka pomiškiui, trakui, žolinei bei samanų dangai
}

\author{
Vitas Marozas, \\ Jurgita Baranauskaitè, \\ Kęstutis Pètelis \\ Aleksandro Stulginskio universitetas, \\ Studentu g. 11, \\ LT-53361 Akademija, Kauno r. \\ El.paštas:vitas.marozas@asu.lt
}

\begin{abstract}
Darbo tikslas - ištirti introdukuotų, aptvare laikomų danielių poveiki miško augalijai: pomiškiui, trakui, žolinei dangai bei samanoms. Tyrimai atlikti 2005$2012 \mathrm{~m}$. Anykščị urédijos Mikierių girininkijos aptvare, dviejuose nuolatiniuose bareliuose: eglès su beržu medyne 20 metrų nuo šèryklos ir eglyne, aptvaro viduryje. Barelio plotas $100 \mathrm{~m}^{2}$. Kiekvienas barelis buvo suskirstytas i 25 apskaitos plotelius $\left(2 \times 2 \mathrm{~m}^{2}\right.$ ploto), kuriuose suskaičiuoti visi pomiškio medeliai, trako krūmai, nurodytos jų rūšys, taip pat nustatyta krūmokšnių, žolinių augalų ir samanų rūšinè sudètis bei kiekvienos rūšies projekcinè danga procentais. Nustatyta, kad per septynerius metus laikant danielius aptvare sumažějo pomiškio ir trako vidutine projekcinè danga, Alnus incana, Picea abies ir Sorbus aucuparia medelių skaičius. Taip pat sumažèjo žolinès dangos projekcinè danga, Calamagrostis arundinacea, Carex digitata, Deschampsia cespitosa, Oxalis acetosella, Maianthemum bifolium, Mycelis muralis, Rubus idaeus vidutinè projekcinė danga. Samanų danga per septynerius metus padidejo. Laikant danielius aptvare stipriausiai ir greičiausiai jų poveikis išryškejjo pomiškiui bei trakui, šiek tiek mažiau žolinei dangai ir mažiausia - samanoms. Danielių poveikis labiausiai išryškèjo po 3-4 metų, kai gyvūnų skaičius aptvare buvo didžiausias. Sumažèjus danielių, pirmiausiai pradèjo atsistatyti žolinė danga, o vèliau vèl atsirado pomiškio ir trako medelių.
\end{abstract}

Raktažodžiai: elniniai žvèrys, kanopiniai, projekcinis padengimas, samanos, žolès

\section{IVADAS}

Dirbtinė gyvūnų aklimatizacija atliekama jau labai seniai. Iš karto ji buvo atsitiktinè bei stichine, o vèliau tapo jau planinga, apgalvota. Žinduoliai aklimatizuojami dèl ịvairių priežasčių: nykstančioms rūšims gelbèti, retų gyvūnų populiacijoms gausinti, nuskurdusiems gyvosios gamtos ištekliams atkurti, medžioklès plotų produktyvumui didinti (Pètelis, 2002). Paprastai aklimatizacija trikdo nusistovejusią ekologinę pusiausvyrą, keičia per evoliuciją susidariusias mitybos grandis, gali slopinti, išstumti vietines rūšis.

Aklimatizacijos procesas yra gana sudètingas. Atvežti žvèrys turi prisitaikyti prie naujų aplinkos sąlygų, klimato, apsisaugoti nuo plèšrūnų, įvairių ligų. Dèl to aklimatizuojant žinduolius būtina, kad dvi ar trys žvérių kartos užaugtų nelaisvejje. Taip jie pereina pirmają aklimatizacijos stadiją - adaptaciją ir lengviau prisitaiko prie naujų klimato, gamtinių sąlygų.

Žvèrių laikymas aptvaruose daro didelị poveiki ten augančiai augalijai. Tam ittakos turi aptvaro dydis, žverių gausa, jų aktyvumas ir kt. Didžiausias poveikis pastebimas pomiškiui, trakui, žolinei augalijai ir samanų dangai (Miller et al., 1992; Gill, 1992, 2001; Baines et al., 1994; Hobs, 1996; Rooney, Dress, 1997; Morecroft et al., 2001; Rooney, 2001; Bradshaw, 2003; Motta, 2003; Rooney, Walter, 2003; Joys et al., 2004; Ruzicka et al., 2010). Tai ypač išryškeja apvaruose, kuriuose didelis žvèriu tankumas.

Danieliai (Cervus dama LINNE, 1758) buvo pirmieji Lietuvoje introdukuojami žvèrys. I Lietuvą jie greičiausiai buvo atvežti dar XVII a. ir veisiami parkuose kaip papuošalas bei medžioklès miškuose kaip vertingas medžioklès laimikis. 1940 m. 
medžiojamosios faunos apskaitos duomenimis, danielių buvo Joniškio, Kuršènų bei Šiaulių miškų uredijose. Pokario metais daugiausia jų buvo priskaičiuojama Akmenès ir Šiaulių r. - nuo 21 (1948) iki 350 (1969), bet, mokslininkų nuomone, po karo danielių nebebuvo arba jie greitai išnyko, o klaidingai danieliais buvo laikomi jauni taurieji elniai (Baleišis ir kt., 2003). Nauja danielių aklimatizacija pradèta 1976-1977 m., kai i Šilutès bei Marijampolès r. ịrengtus aptvarus išleista 90 danielių (Pètelis, 2002). Šiuo metu šalyje iš žinduolių realiai vyksta tik danielių aklimatizacija ir ji vis aktyvèja.

Danielių aklimatizacija, jos eiga Lietuvoje yra nemažai tyrinèta (Pètelis, 1998, 2002, 2004, 2010; Petelis, Brazaitis, 2005; Pètelis ir kt., 2010), bet mažai tyrinètas jų poveikis augalijai (Marozas et. al., 2009). Paleisti ị laisvę danieliai yra palyginti sèslūs ir jų elementarioji populiacija gali pasiekti gana didelị tankị (Pètelis, 2002). Išaugus tankiui, jie gali stipriai veikti miško augaliją. Be to, naujai introdukuotos rūšys, mūsų atveju, - danieliai, gali daryti didesnị poveikị skirtingoms miško augalijos rūšims nei vietinès rūšys. Danieliai prieš išleidžiant ị laisvę dažniausiai tam tikrą laiką yra laikomi aptvaruose, kur pereina pirmines aklimatizacijos stadijas. Kai jie apgyvendinami naujai îrengtame aptvare, čia galima stebèti danielių poveiki atskiroms miško augalijos rūšims. Kadangi danielių tankis aptvare auga greitai, susidaro puikios sąlygos stebèti jų gausos kitimo poveikị miško augalijai.

Šio darbo tikslas - ištirti Anykščių urèdijos, Mikierių girininkijos, Šimonių girios aptvare laikomų danielių poveiki miško augalijai: pomiškiui, trakui, žolinei augalijai ir samanų dangai.

\section{TYRIMŲ METODAI IR SĄLYGOS}

Siekiant išaiškinti aptvaruose laikomų laukinių gyvūnų poveiki pomiškiui, trakui, žolinei dangai ir samanoms, buvo atlikti tyrimai Anykščių uredijos Mikieriu girininkijos aptvare, kuriame laikomi danieliai. Apvaras ịrengtas 2005 m. Anykščių miškų urèdijos Mikieriu girininkijoje 51 kvartalo 3-18 sklypuose, 63 kvartalo 1-23, 28, 33 sklypuose (1 pav.).

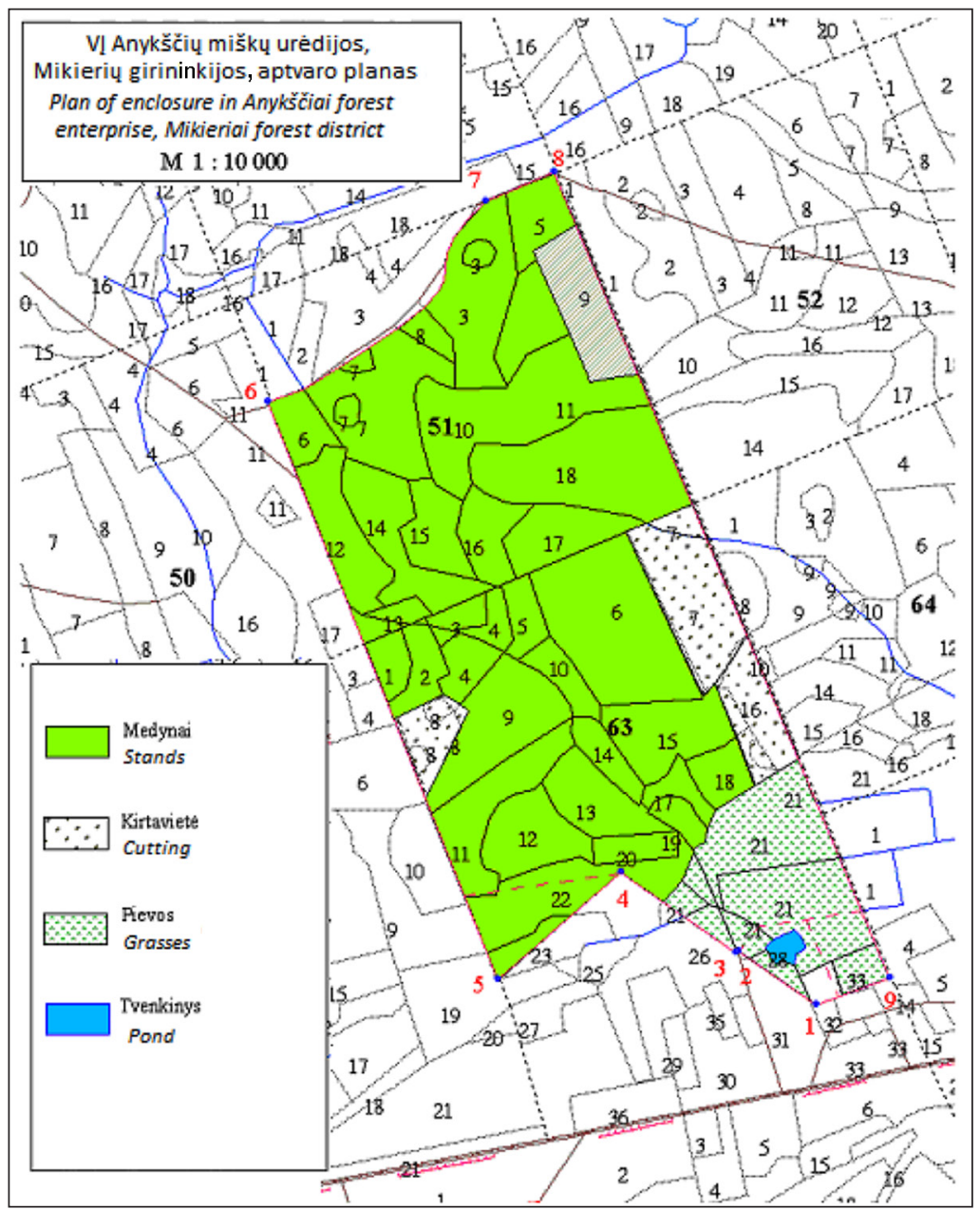

1 pav. Danielių aptvaro Anykščių urèdijos Mikierių girininkijoje planas

Fig. 1. Plan of the fenced area in Mikieriai forest district of Anykščiai forest enterprise 
Aptvaro plotas - 62,9 ha, iš jų - 48,4 ha užima medynai, 7,0 ha - kirtavietes, 7,3 ha - pievos, ganyklos, pašarinès aikštelès, $0,2 \mathrm{ha}$ - vandens tvenkinys.

Pirmieji danieliai (20) įaptvarą buvo įleisti $2005 \mathrm{~m}$; 2006 m. jų buvo 28; 2007 m. - 36; 2008 m. - 60; 2009 m. - 90. Nuo 2010 m. dalis gyvūnų buvo paleidžiami ị laisvę. $2010 \mathrm{~m}$. aptvare jau buvo 30, 2011-2012 m. - 25 danieliai.

Aptvare 2005 m. žemutinių miško ardų augalijai stebèti buvo ịrengti nuolatiniai bareliai. Aanalizuojame 2 barelių, ikkurtų eglyne, su beržu 20 metrų nuo šeryklos ir eglyne aptvaro viduryje, duomenis. Kiekvieno jų plotas $-100 \mathrm{~m}^{2}$. Kiekvienas barelis buvo suskirstytas i 25 apskaitos plotelius $\left(2 \times 2 \mathrm{~m}^{2}\right.$ ploto $)$, kuriuose buvo suskaičiuoti visi pomiškio medeliai, trako krūmai, nurodytos jų rūšys. Pagal žvėrių padarytus pažeidimus, jie suskirstyti i pažeistus ir sveikus. Taip pat nustatyta krūmokšnių, žolinių augalų ir samanų rūšinė sudètis bei kiekvienos rūšies projekcinè danga procentais. Augalu pavadinimai pateikti pagal Z. Gudžinską (1999). Tyrimai atlikti 2005-2012 m. Siekiant išvengti sezono ittakos, kiekvienais metais augalų dangos tyrimai atlikti liepos mèn. Pakankamai ilgas (7 metai) stebejimų laikas leidžia atskleisti augalijos kitimo tendencijas (dèl aptvare laikomų danielių poveikio). Atskirų rūšių pokyčių skirtumas ivertintas, panaudojus neparametrini Friedman testą, skirtą priklausomoms imtims.

\section{TYRIMŲ REZULTATAI IR JŲ APTARIMAS}

\section{Pomiškio, trako, žolinès ir samanų dangos pokyčiai eglès medyne su beržu $20 \mathrm{~m}$ nuo šèryklos}

Pomiškio projekcinè danga $2005 \mathrm{~m}$. buvo 31,92\% ir palaipsniui mažejo. Ypač ji sumažèjo 2007 m., o 2011 m. apskritai išnyko. 2012 m. pomiškio vèl šiek tiek atsirado (1 lentelè).
Trako projekciné danga 2005-2006 m. buvo 4,92 \%, 2007 m. labai sumažèjo (iki 0,46 \%) ir mažejo iki $2011 \mathrm{~m}$., kol trakas visai išnyko. $2012 \mathrm{~m}$. trako vèl šiek tiek atsirado (1 lentelè).

2005-2006 m. žolinès dangos vidutinis padengimas nesikeite ir buvo 15,88\%. Nuo 2007 iki 2009 m. žolių vidutinè danga labai sumažèjo. Šis pokytis ívyko dèl to, kad iki 2009 m. sparčiai pagausèjo danielių. 2010 m. sumažejus danielių, žolinè danga èmè gausèti (1 lentelè).

2005-2006 m. samanų vidutinè projekcinè danga siekè 4,36 \%, 2007 m. padidejjo iki 13,48\% ir palaipsniui didèjo iki $2010 \mathrm{~m}$. (31,44 \%). Toki pokyti galëjo lemti sumažèęs pomiškis ir trakas. Nuo 2011 m. samanų danga vèl mažèjo, 2012 m. siekè $22,62 \%$ (1 lentelè).

2005-2012 m. pomiškyje buvo nustatytos šios medžių rūšys: Betula pendula, Piciea abies, Рopulus tremula ir Quercus robur (2 lentelè). Daugiausia buvo Picea abies, Alnus incana ir Populus tremula medelių. 2007-2008 m., palyginti su 2005 m., neliko Betula pendula, Populus tremula ir Quercus robur medelių (2 lentelè).

2007 m. sumažèjo sveikų, o padaugèjo pažeistų eglių. Tam ittakos turejo danielių skaičiaus didèjimas. $2008 \mathrm{~m}$. padaugèjo sveikų, o sumažėjo pažeistų eglių. 2009 m. sveikų eglių kiekis vẻl mažèjo, kol 2011 m. visai išnyko ir labai sumažejo pažeistų. 2012 m. sveikų ir pažeistų eglių šiek tiek padaugèjo (2 lentelè).

2007 m. sveikų baltalksnių pradèjo mažèti, 2010 m. jie išnyko. Pažeistų baltalksnių $2007 \mathrm{~m}$. pradèjo mažèti, kol $2011 \mathrm{~m}$. visai išnyko. $2012 \mathrm{~m}$. vèl aptikta šiek tiek pažeistų baltalksnių (2 lentelè).

Trake nustatytos šios rūšys: Frangula alnus, Rhamnus cathartica, Ribes rubrum, Salix cinerea ir Sorbus aucuparia. 2007 m. išnyko Salix cinerea, o 2008 m. - Rhamnus cathartica, Ribes rubrum ir

1 lentelè. Pomiškio, trako, žolinės ir samanų dangos vidutinè projekcinè danga 2005-2012 m. eglès medyne su beržu

Table 1. Average projection cover of saplings, undergrowth, herb layers and mosses in the spruce stand with birch from 2005 to 2012

\begin{tabular}{c|c|c|c|c|c|c|c|c|c}
\hline \multirow{2}{*}{$\begin{array}{c}\text { Miško ardas } \\
\text { Forest layer }\end{array}$} & \multicolumn{7}{|c|}{ Vidutinè projekcinė danga \% / Average projection cover, \% } & \multirow{2}{*}{ p } \\
\cline { 2 - 12 } & $\mathbf{2 0 0 5}$ & $\mathbf{2 0 0 6}$ & $\mathbf{2 0 0 7}$ & $\mathbf{2 0 0 8}$ & $\mathbf{2 0 0 9}$ & $\mathbf{2 0 1 0}$ & $\mathbf{2 0 1 1}$ & $\mathbf{2 0 1 2}$ & \\
\hline Pomiškis / Saplings & 32,92 & 32,72 & 18,72 & 16,48 & 11,56 & 3,29 & 0 & 0,05 & 0,000 \\
\hline Trakas / Undergrowth & 4,92 & 4,92 & 0,46 & 0,052 & 0,06 & 0,01 & 0 & 0,01 & 0,000 \\
\hline Žolès / Herbs & 15,88 & 15,88 & 5,84 & 4,52 & 4,24 & 8,64 & 5,84 & 4,15 & 0,000 \\
\hline Samanos / Mosses & 4,36 & 4,36 & 13,48 & 16,2 & 28,04 & 31,44 & 25,76 & 22,62 & 0,000 \\
\hline
\end{tabular}

Pastaba / Note: $\mathrm{p}$ - Friedman neparametrinis testas / Friedman nonparametric test. 
2 lentelè. Pomiškio ir trako rūšiu vidutinis kiekis 2005-2012 m. eglès medyne su beržu

Table 2. Average amount of sapling and undergrowth species in the spruce stand with birch from 2005 to 2012

\begin{tabular}{|c|c|c|c|c|c|c|c|c|c|}
\hline \multirow{2}{*}{$\begin{array}{l}\text { Rūšies pavadinimas } \\
\text { Name of species }\end{array}$} & \multicolumn{8}{|c|}{ Vidutinis kiekis vnt. $\mathrm{m}^{-2} /$ Average amount, unit $\mathrm{m}^{-2}$} & \multirow{2}{*}{$\mathbf{p}$} \\
\hline & 2005 & 2006 & 2007 & 2008 & 2009 & 2010 & 2011 & 2012 & \\
\hline \multicolumn{10}{|c|}{ Pomiškis / Saplings } \\
\hline Alnus incana & 0,130 & 0,130 & 0,030 & 0,021 & 0,001 & 0 & 0 & 0 & 0,000 \\
\hline Alnus incana ${ }^{*}$ & 0,010 & 0,010 & 0,090 & 0,080 & 0,070 & 0,050 & 0 & 0,010 & 0,044 \\
\hline Betula pendula & 0,030 & 0,030 & 0 & 0 & 0 & 0 & 0 & 0 & 0,007 \\
\hline Picea abies & 2,520 & 2,120 & 0,321 & 1,200 & 1,110 & 0,050 & 0 & 0,185 & 0,000 \\
\hline Picea abies ${ }^{*}$ & 0,710 & 0,620 & 1,390 & 0,420 & 0,560 & 0,270 & 0,010 & 0,180 & 0,000 \\
\hline Populus tremula & 0,060 & 0,060 & 0 & 0 & 0 & 0 & 0 & 0 & 0,023 \\
\hline Populus tremula* & 0,110 & 0,080 & 0 & 0 & 0 & 0 & 0 & 0 & 0,000 \\
\hline Quercus robur & 0,050 & 0,030 & 0 & 0 & 0 & 0 & 0 & 0 & 0,031 \\
\hline Quercus robur* & 0,010 & 0,010 & 0,010 & 0 & 0 & 0 & 0 & 0 & 0,773 \\
\hline \multicolumn{10}{|c|}{ Trakas / Undergrowth } \\
\hline Frangula alnus & 0 & 0 & 0 & 0,030 & 0,020 & 0,011 & 0,011 & 0,011 & 0,313 \\
\hline Frangula alnus ${ }^{*}$ & 0,020 & 0,020 & 0 & 0 & 0 & 0 & 0 & 0 & 0,089 \\
\hline Rhamnus cathartica & 0,020 & 0,020 & 0,010 & 0 & 0 & 0 & 0 & 0 & 0,628 \\
\hline Rhamnus cathartica* & 0,030 & 0,030 & 0,060 & 0,030 & 0 & 0 & 0 & 0 & 0,609 \\
\hline Ribes rubrum & 0,060 & 0,060 & 0,070 & 0,010 & 0 & 0 & 0 & 0 & 0,391 \\
\hline Salix cinerea & 0,010 & 0,010 & 0 & 0 & 0 & 0 & 0 & 0 & 0,536 \\
\hline Salix cinerea & 0,020 & 0,020 & 0 & 0 & 0 & 0 & 0 & 0 & 0,089 \\
\hline Sorbus aucuparia & 0,120 & 0,120 & 0 & 0 & 0 & 0 & 0 & 0 & 0,016 \\
\hline Sorbus aucuparia* & 0,180 & 0,180 & 0,050 & 0 & 0 & 0 & 0 & 0 & 0,000 \\
\hline
\end{tabular}

Pastaba / Note: ${ }^{*}$ - pažeisti / browsed; p - Friedman neparametrinis testas / Friedman nonparametric test.

Sorbus aucuparia. Frangula alnus neliko 2007 m., bet vèliau nedaug jo buvo aptinkama visu tiriamuoju laikotarpiu (2 lentelè).

Gausiausios žolių rūšys buvo Oxalis acetosella, Calamagrostis arundinacea, Dryopteris carthusania, Rubus idaeus, Deschampsia cespitosa (3 lentelè). Šios rūšys nuosekliai mažèjo iki 2008-2009 m. Vèliau, sumažèjus aptvare danielių kiekiui, jų šiek tiek pradejo daugeti. Čia taip pat negausiai augo: Maianthemum bifolium, Pteridium aquilinum, Fragaria vesca, Agrostis capillaris, Stellaria nemorum, Viola riviniana, Cystopteris fragilis, Trientalis europaea, Luzula pilosa, Potentilla erecta, Urtica dioica, Gymnocarpium dryopteris, Galeopsis sp., Paris quadrifolia, Lycopodium clavatum, Vaccinium myrtillus, Carex digitata. Vèlesniais metais dar atsirado: Mycelis muralis, Stellaria media, Poa trivialis, Rumex acetosella, Solidago virgaurea, Veronica chamaedrys, Lysimachia vulgaris, Chenopodium sp., Galium aparine, Convolvulus sp., Athyrium filixfemina (3 lentelè).

Nustatytos samanų rūšys: Pleurozium schereberi, Plagiomnium sp., Hylocomium splendens,
Atrichum undulatum, Polytrichum commune ir Dicranum scoparium. Gausiausia samanų rūšis Pleurozium schereberi. Samanų danga didejo iki 2010 m., o vèliau pradejo mažèti (3 lentelè).

\section{Pomiškio, trako, žolinès ir samanų dangos pokyčiai eglès medyne, aptvaro viduryje}

2005-2006 m. pomiškio vidutinè danga buvo 0,21\%, vèliau mažejo. 2007-2009 m. vidutinè pomiškio danga sumažèjo iki $0,15-0,16 \%$; dar labiau sumažèjo 2012 m. - iki 0,06 \% (4 lentelè).

Trako vidutiné projekciné danga 2005-2006 m. siekè 0,35 \%. $2007 \mathrm{~m}$. vidutinè trako danga sumažejo iki $0,08 \%$ ir vèlesniais metais nuosekliai mažèjo (4 lentelè).

Žolinès dangos vidutinè projekcinè danga 2005-2006 m. buvo 21,8 \%, $2007 \mathrm{~m}$. sumažejo iki $9 \%$. Labiausiai danielių poveikis žolinei dangai pasireiške 2009 m., kai ji sumažejo iki 5,12 \% (tuo metu danielių skaičius aptvare buvo didžiausias). 2010 m. žolinè danga pradèjo didèti, nes dalis danielių iš aptvaro buvo paleisti ị laisvę. $2012 \mathrm{~m}$. žolinè danga vèl šiek tiek sumažèjo (4 lentelè). 
3 lentelè. Žolinès ir samanų dangos rūšių vidutinè projekcinè danga 2005-2012 m. eglès medyne su beržu

Table 3. Average projection cover of herbs and moss species in the spruce stand with birch from 2005 to 2012

\begin{tabular}{|c|c|c|c|c|c|c|c|c|c|}
\hline \multirow{2}{*}{$\begin{array}{l}\text { Rūšies pavadinimas } \\
\text { Name of species }\end{array}$} & \multicolumn{8}{|c|}{ Vidutinė projekcinė danga \% / Average projection cover, \% } & \multirow{2}{*}{$\mathbf{p}$} \\
\hline & 2005 & 2006 & 2007 & 2008 & 2009 & 2010 & 2011 & 2012 & \\
\hline \multicolumn{10}{|c|}{ Žolès / Herbs } \\
\hline Oxalis acetosella & 4,688 & 4,688 & 1,968 & 1,536 & 1,812 & 3,768 & 2,4 & 1,927 & 0,000 \\
\hline Calamagrostis arundinacea & 3,848 & 3,848 & 1,492 & 0,984 & 0,476 & 0,432 & 0,148 & 0,038 & 0,000 \\
\hline Dryopteris carthusania & 1,980 & 1,980 & 0,948 & 0,880 & 0,868 & 1,456 & 0,948 & 0,873 & 0,152 \\
\hline Rubus idaeus & 1,688 & 1,688 & 0,396 & 0,244 & 0,128 & 0,48 & 0,16 & 0,134 & 0,000 \\
\hline Deschampsia cespitosa & 1,000 & 1,000 & 0,260 & 0,148 & 0,076 & 0,04 & 0,044 & 0,042 & 0,000 \\
\hline Maianthemum bifolium & 0,684 & 0,684 & 0,26 & 0,032 & 0,032 & 0,036 & 0,008 & 0,011 & 0,112 \\
\hline Pteridium aquilinum & 0,440 & 0,440 & 0,444 & 0,204 & 0,164 & 0,244 & 0,204 & 0,119 & 0,904 \\
\hline Fragaria vesca & 0,324 & 0,324 & 0,02 & 0,024 & 0,024 & 0,024 & 0,008 & 0,019 & 0,074 \\
\hline Agrostis capillaris & 0,244 & 0,244 & 0,024 & 0,168 & 0,556 & 1,152 & 1,032 & 0,765 & 0,006 \\
\hline Stellaria nemorum & 0,240 & 0,240 & 0,004 & 0,012 & 0,012 & 0,008 & 0,007 & 0,007 & 0,339 \\
\hline Viola riviniana & 0,136 & 0,136 & 0,020 & 0,016 & 0,056 & 0,072 & 0,044 & 0,069 & 0,333 \\
\hline Cystopteris fragilis & 0,140 & 0,140 & 0,060 & 0,020 & 0,020 & 0,004 & 0 & 0 & 0,008 \\
\hline Trientalis europaea & 0,104 & 0,104 & 0,04 & 0,044 & 0,048 & 0,056 & 0,012 & 0,015 & 0,158 \\
\hline Luzula pilosa & 0,044 & 0,044 & 0,044 & 0,068 & 0,068 & 0,056 & 0,008 & 0,058 & 0,201 \\
\hline Potentilla erecta & 0,044 & 0,044 & 0,004 & 0,004 & 0,004 & 0,008 & 0 & 0 & 0,512 \\
\hline Urtica dioica & 0,040 & 0,040 & 0,040 & 0,132 & 0,060 & 0,216 & 0,292 & 0,396 & 0,042 \\
\hline Gymnocarpium dryopteris & 0,040 & 0,040 & 0,004 & 0,008 & 0,048 & 0,088 & 0,008 & 0,081 & 0,772 \\
\hline Galeopsis sp. & 0,012 & 0,012 & 0,008 & 0 & 0,004 & 0,008 & 0 & 0,004 & 0,416 \\
\hline Paris quadrifolia & 0,008 & 0,008 & 0,008 & 0 & 0 & 0 & 0,004 & 0 & 0,322 \\
\hline Lycopodium clavatum & 0,008 & 0,008 & 0 & 0 & 0 & 0 & 0 & 0 & 0,082 \\
\hline Vaccinium myrtillus & 0,004 & 0,004 & 0 & 0,004 & 0,004 & 0,004 & 0 & 0 & 0,879 \\
\hline Carex digitata & 0,004 & 0,004 & 0 & 0 & 0 & 0,004 & 0,004 & 0 & 0,782 \\
\hline Mycelis muralis & 0 & 0 & 0,012 & 0,028 & 0,024 & 0,076 & 0,028 & 0,031 & 0,022 \\
\hline Stellaria media & 0 & 0 & 0,004 & 0,02 & 0,028 & 0,108 & 0,024 & 0,031 & 0,170 \\
\hline Poa trivialis & 0 & 0 & 0,004 & 0,02 & 0,06 & 0,132 & 0,132 & 0,0841 & 0,681 \\
\hline Rumex acetosella & 0 & 0 & 0 & 0,004 & 0,012 & 0,012 & 0,008 & 0,011 & 0,194 \\
\hline Solidago virgaurea & 0 & 0 & 0 & 0 & 0,004 & 0,004 & 0,004 & 0,004 & 0,783 \\
\hline Veronica chamaedrys & 0 & 0 & 0 & 0,008 & 0,020 & 0,016 & 0,004 & 0,015 & 0,020 \\
\hline Lysimachia vulgaris & 0 & 0 & 0 & 0 & 0,004 & 0,004 & 0 & 0,004 & 0,655 \\
\hline Chenopodium sp. & 0 & 0 & 0 & 0,004 & 0,004 & 0,004 & 0 & 0,004 & 0,773 \\
\hline Galium aparine & 0 & 0 & 0 & 0,004 & 0,004 & 0 & 0 & 0,004 & 0,652 \\
\hline Convolvulus sp. & 0 & 0 & 0 & 0 & 0 & 0,004 & 0,004 & 0,004 & 0,532 \\
\hline Athyrium filix-femina & 0 & 0 & 0 & 0 & 0 & 0,004 & 0,004 & 0,004 & 0,472 \\
\hline \multicolumn{10}{|c|}{ Samanos / Mosses } \\
\hline Pleurozium schereberi & 3,520 & 3,520 & 9,960 & 13,520 & 21,880 & 24,920 & 19,720 & 17,044 & 0,000 \\
\hline Plagiomnium sp. & 0,360 & 0,360 & 2,444 & 2,252 & 3,600 & 4,164 & 3,524 & 3,364 & 0,000 \\
\hline Hylocomium splendens & 0,240 & 0,240 & 0,600 & 0,600 & 1,560 & 1,520 & 1,280 & 0,920 & 0,021 \\
\hline Atrichum undulatum & 0,120 & 0,120 & 0,280 & 0,280 & 0,480 & 0,960 & 0,524 & 0,572 & 0,475 \\
\hline Polytrichum commune & 0,160 & 0,160 & 0,200 & 0,160 & 0,484 & 0,484 & 0,640 & 0,560 & 0,601 \\
\hline Dicranum scoparium & 0,044 & 0,044 & 0,004 & 0 & 0 & 0 & 0,040 & 0,004 & 0,613 \\
\hline
\end{tabular}

Pastaba / Note: p - Friedman neparametrinis testas / Friedman nonparametric test. 
4 lentelè. Pomiškio, trako, žolinès ir samanų dangos vidutinė projekcinė danga 2005-2012 m. eglès medyne, atvaro viduryje

Table 4. Average projection cover of saplings, undergrowth, herb layers and mosses in the spruce stand in the middle of the enclosure from 2005 to 2012

\begin{tabular}{|c|c|c|c|c|c|c|c|c|c|}
\hline \multirow{2}{*}{$\begin{array}{c}\text { Miško ardas } \\
\text { Forest layer }\end{array}$} & \multicolumn{8}{|c|}{ Vidutinè projekcinè danga \% / Average projection cover, \% } & \multirow{2}{*}{$\mathbf{p}$} \\
\hline & 2005 & 2006 & 2007 & 2008 & 2009 & 2010 & 2011 & 2012 & \\
\hline Pomiškis / Saplings & 0,21 & 0,21 & 0,15 & 0,16 & 0,16 & 0,14 & 0,13 & 0,06 & 0,519 \\
\hline Trakas / Undergrowth & 0,35 & 0,35 & 0,08 & 0,06 & 0,04 & 0,04 & 0,02 & 0,02 & 0,007 \\
\hline Žolès / Herbs & 21,80 & 21,80 & 9,00 & 5,32 & 5,12 & 7,00 & 10,32 & 7,96 & 0,000 \\
\hline Samanos / Mosses & 57,20 & 57,20 & 61,20 & 63,00 & 73,20 & 75,60 & 77,60 & 79,60 & 0,000 \\
\hline
\end{tabular}

Pastaba / Note: p - Friedman neparametrinis testas / Friedman nonparametric test.

Samanų vidutinė projekcinè danga nuosekliai didejo (4 lentelè). 2005-2006 m. samanų vidutinè danga barelyje buvo 57,2 \%, o 2012 m. - 79,6 \%. Ši padidejimą galèjo lemti sumažèjusios pomiškio, trako ir žolinès dangos.

2005-2012 m. pomiškyje buvo nustatytos šios medžių rūšys: Betula pendula, Picea abies ir Quercus robur (5 lentelè). Daugiausia buvo Picea abies medelių. 2007 m. neliko Quercus robur, o 2009 Betula pendula. Picea abies medeliu labiausiai sumažèjo 2007 m., vèliau jų dar mažèjo 2009-2011 m. (5 lentelè).

Trake nustatytos šios rūšys: Corylus avellana, Frangula alnus ir Sorbus aucuparia. Gausesnè buvo Sorbus aucuparia, tačiau ir ji nuo 2005 m. nuosekliai mažèjo (5 lentelè).

Gausiausios žolių rūšys: Oxalis acetosella, Vaccinium myrtillus, Calamagrostis arundinacea, Maianthemum bifolium, Rubus saxatilis, Carex digitata (6 lentelè). Šių rūšių gausumas nuosekliai mažejo iki 2009-2010 m., vèliau pradèjo šiek tiek didèti (lèmè aptvare sumažėjęs danielių kiekis). Negausiai augo: Mycelis muralis, Viola arvensis, Luzula pilosa, Vaccinium vitis-idaea, Galium aparine, Athyrium filix-femina, Pyrola rotundifolia, Lysimachia vulgaris, Equisetum arvense, Poa nemoralis, Solidago virgaurea, Agrostis capillaris, Veronica chamaedrys, Veronica officinalis. Vèlesniais metais dar atsirado: Rubus idaeus, Fragaria vesca, Deschampsia caespitosa, Viola riviniana, Stellaria media (6 lentelè).

Nustatytos samanų rūšys: Hylocomium splendens, Pleurozium schereberi, Plagiomnium affine, Rhytidiadelphus triquetrus, Eurhynchium angustirete, Dicranum scoparium. Gausiausios samanų rūšys - Hylocomium splendens, Pleurozium schereberi, Plagiomnium affine. Samanų danga pamažu didèjo (6 lentelè).

Didžiausias danielių poveikis buvo pomiškiui ir trakui. Sunyko ne tik lapuočiu medeliai, bet ir eglès pomiškis, nors šis elninių žvèrių yra ir mažiau

5 lentelè. Pomiškio ir trako rūšiu vidutinis kiekis 2005-2012 m. eglès medyne, atvaro viduryje

Table 5. Average amount of saplings and undergrowth species in the spruce stand in the middle of the enclosure from 2005 to 2012

\begin{tabular}{|c|c|c|c|c|c|c|c|c|c|}
\hline \multirow{2}{*}{$\begin{array}{l}\text { Rūšies pavadinimas } \\
\text { Name of species }\end{array}$} & \multicolumn{8}{|c|}{ Vidutinis kiekis vnt. $\mathrm{m}^{-2} /$ Average amount, unit $\mathrm{m}^{-2}$} & \multirow{2}{*}{$\mathbf{p}$} \\
\hline & 2005 & 2006 & 2007 & 2008 & 2009 & 2010 & 2011 & 2012 & \\
\hline \multicolumn{10}{|c|}{ Pomiškis / Saplings } \\
\hline Picea abies & 25,240 & 25,240 & 11,320 & 11,920 & 7,920 & 4,000 & 2,680 & 2,680 & 0,000 \\
\hline Picea abies ${ }^{\star}$ & 0 & 0 & 0,060 & 0 & 0 & 0,410 & 0,311 & 0,410 & 0,046 \\
\hline Betula pendula & 0,030 & 0,030 & 0,010 & 0,010 & 0 & 0 & 0 & 0 & 0,083 \\
\hline Quercus robur & 0,010 & 0,010 & 0 & 0 & 0 & 0 & 0 & 0 & 0,659 \\
\hline \multicolumn{10}{|c|}{ Trakas / Undergrowth } \\
\hline Sorbus aucuparia & 0,020 & 0,020 & 0,020 & 0,028 & 0,012 & 0,011 & 0,001 & 0,001 & 0,718 \\
\hline Sorbus aucuparia* & 0,360 & 0,360 & 0,260 & 0,200 & 0,160 & 0,12 & 0,040 & 0,040 & 0,002 \\
\hline Frangula alnus ${ }^{*}$ & 0,070 & 0,070 & 0,010 & 0,010 & 0,010 & 0,010 & 0,010 & 0,010 & 0,760 \\
\hline Corylus avellana & 0,010 & 0,010 & 0,001 & 0,010 & 0,001 & 0 & 0 & 0 & 0,076 \\
\hline
\end{tabular}

Pastaba / Note: ${ }^{*}$ - pažeisti / browsed; p - Friedman neparametrinis testas / Friedman nonparametric test. 
6 lentelè. Žolinès ir samanų dangos rūšiu vidutinè projekcinè danga 2005-2012 m. eglès medyne, aptvaro viduryje

Table 6. Average projection cover of herbs and moss species in the spruce stand in the middle of the enclosure from 2005 to 2012

\begin{tabular}{|c|c|c|c|c|c|c|c|c|c|}
\hline \multirow{2}{*}{$\begin{array}{l}\text { Rūšies pavadinimas } \\
\text { Name of species }\end{array}$} & \multicolumn{8}{|c|}{ Vidutinè projekcinè danga \% / Average projection cover, \% } & \multirow{2}{*}{$\mathbf{p}$} \\
\hline & 2005 & 2006 & 2007 & 2008 & 2009 & 2010 & 2011 & 2012 & \\
\hline \multicolumn{10}{|c|}{ Žolès / Herbs } \\
\hline Oxalis acetosella & 11,600 & 11,600 & 5,880 & 2,760 & 2,600 & 4,600 & 4,800 & 3,444 & 0,000 \\
\hline Vaccinium myrtillus & 5,808 & 5,808 & 2,444 & 1,372 & 0,976 & 0,788 & 1,660 & 1,100 & 0,186 \\
\hline Calamagrostis arundinacea & 2,364 & 2,364 & 1,600 & 1,000 & 0,848 & 0,884 & 1,204 & 1,208 & 0,441 \\
\hline Maianthemum bifolium & 1,512 & 0,148 & 0,076 & 0,108 & 0,072 & 0,072 & 0,040 & 0,040 & 0,000 \\
\hline Rubus saxatilis & 1,500 & 1,500 & 1,096 & 0,700 & 0,176 & 0,060 & 0,056 & 0,052 & 0,000 \\
\hline Carex digitata & 1,296 & 1,296 & 0,284 & 0,148 & 0,112 & 0,112 & 0,116 & 0,080 & 0,000 \\
\hline Mycelis muralis & 0,576 & 0,576 & 0,036 & 0,044 & 0,052 & 0,072 & 0,044 & 0,048 & 0,000 \\
\hline Viola arvensis & 0,384 & 0,384 & 0,052 & 0,060 & 0,06 & 0,068 & 0,064 & 0,060 & 0,000 \\
\hline Luzula pilosa & 0,176 & 0,176 & 0,032 & 0,040 & 0,044 & 0,044 & 0,044 & 0,036 & 0,009 \\
\hline Vaccinium vitis-idaea & 0,124 & 0,124 & 0,096 & 0,060 & 0,020 & 0,020 & 0,012 & 0,012 & 0,183 \\
\hline Galium aparine & 0,084 & 0,008 & 0,008 & 0,008 & 0,008 & 0,012 & 0,012 & 0,016 & 0,566 \\
\hline Athyrium filix-femina & 0,080 & 0,080 & 0,080 & 0,080 & 0,040 & 0,040 & 0,044 & 0,040 & 0,991 \\
\hline Pyrola rotundifolia & 0,040 & 0,040 & 0,012 & 0,012 & 0,008 & 0 & 0 & 0 & 0,686 \\
\hline Lysimachia vulgaris & 0,020 & 0,020 & 0,016 & 0,020 & 0,020 & 0,024 & 0,016 & 0,052 & 0,802 \\
\hline Equisetum arvense & 0,008 & 0,008 & 0,004 & 0,004 & 0,004 & 0,004 & 0,004 & 0,004 & 0,891 \\
\hline Poa nemoralis & 0,004 & 0,004 & 0 & 0 & 0 & 0 & 0 & 0 & 0,541 \\
\hline Solidago virgaurea & 0,004 & 0,004 & 0,004 & 0 & 0 & 0 & 0,004 & 0 & 0,778 \\
\hline Agrostis capillaris & 0,008 & 0,008 & 0,004 & 0,004 & 0,008 & 0,008 & 0,012 & 0,012 & 0,952 \\
\hline Veronica chamaedrys & 0,004 & 0,004 & 0 & 0 & 0 & 0 & 0 & 0 & 0,542 \\
\hline Veronica officinalis & 0,004 & 0,004 & 0 & 0 & 0 & 0 & 0 & 0 & 0,542 \\
\hline Rubus idaeus & 0 & 0 & 0,004 & 0,004 & 0,008 & 0,008 & 0,004 & 0,016 & 0,245 \\
\hline Fragaria vesca & 0 & 0 & 0 & 0,004 & 0,004 & 0,004 & 0,004 & 0,008 & 0,692 \\
\hline Deschampsia caespitosa & 0 & 0 & 0 & 0,004 & 0,004 & 0,004 & 0,004 & 0,004 & 0,883 \\
\hline Viola riviniana & 0 & 0 & 0 & 0 & 0 & 0,004 & 0,008 & 0,004 & 0,321 \\
\hline Stellaria media & 0 & 0 & 0 & 0 & 0 & 0,004 & 0,004 & 0 & 0,542 \\
\hline \multicolumn{10}{|c|}{ Samanos / Mosses } \\
\hline Hylocomium splendens & 28,600 & 28,600 & 29,600 & 30,800 & 32,200 & 32,200 & 33,800 & 31,640 & 0,984 \\
\hline Pleurozium schereberi & 19,800 & 19,800 & 20,400 & 24,000 & 27,760 & 29,560 & 30,760 & 27,000 & 0,015 \\
\hline Plagiomnium affine & 7,600 & 7,600 & 7,040 & 8,240 & 8,040 & 8,000 & 8,800 & 10,000 & 0,981 \\
\hline Rhytidiadelphus triquetrus & 2,480 & 2,480 & 2,280 & 4,080 & 3,960 & 4,040 & 4,040 & 3,724 & 0,937 \\
\hline Eurhynchium angustirete & 1,320 & 1,320 & 1,520 & 1,520 & 2,120 & 2,120 & 2,120 & 2,120 & 0,988 \\
\hline Dicranum scoparium & 0,320 & 0,320 & 0,320 & 0,320 & 0,480 & 0,480 & 0,480 & 0,840 & 0,848 \\
\hline
\end{tabular}

Pastaba / Note: p - Friedman neparametrinis testas / Friedman nonparametric test.

mégiamas. Trako medeliai intensyviai buvo skabomi visame aptvare. Iš trako rūšių labiausiai buvo mėgstami šermukšniai. Žolių projekcinè danga visame aptvare taip pat sumažejo. Labiausiai buvo skabomos Vaccinium myrtillus, Calamagrostis arundinacea, Rubus idaeus. Kitų rūšių - Carex digitata, Oxalis acetosella, Maianthemum bifolium, Mycelis muralis - projekcinès dangos sumažèjimas gali būti siejamas su netiesioginiu žvėrių poveikiu arba tam tikromis fliuktuacijomis. Samanų projekcinè danga tiriamuoju laikotarpiu padidejo. Matyt, turèjo ittakos dèl sunykusio pomiškio bei sumažejusios žolinès dangos padidejjęs apšvietimas.

Didžiausias poveikis buvo šalia žvèrių šèryklos, kur visai sunyko pomiškis ir trakas, sumažèjo žolinè danga. Danielių poveikis labiausiai išryškejo po 3-4 metų, kai jų aptvare buvo daugiausia. Vèliau, sumažejus danielių skaičiui, pirmiausiai pradejo atsistatyti žoline danga, o dar po 3 metų atsirado šiek tiek pomiškio ir trako medelių. 
Kitose šalyse atlikti tyrimai parodè, kad panašūs pokyčiai būna laikant ir kitas elninių žvèrių rūšis (elnius, stirnas). Pirmiausiai sumažèja žvėrių mègiamų rūšių - Vaccinium myrtillus, Rubus sp. Lonicera periclymenum, plinta labiau nemégiamos bei nuodingos augalų rūšys (Pteridium aquilinum, Glechoma hederacea). Gausesnès buvo augalų rūšys, pakenčiančios skabymą, - tai daugiausia varpinès žolès (Pigott, 1983; Putman et al., 1989). Kai kurios augalų rūšys gali būti elninių žvèrių ištrypiamos. J. P. Grime ir kt. (2007) nurodo, kad trypiant nukenčia Mercurialis perennis, todèl jų sumažeja elninių žveerių išmintuose takuose arba žvèriu susibūrimo vietose.

Kai kurioms augalų rūšims elniniai žvèrys, suardydami paklotę, sudaro palankias sąlygas plisti. Tai daugiausiai ruderalinès rūšys (Mycelis muralis, Rumex sp., Senecio jacobea, Sonchus oleraceus) (Kirby, 2001). Dèl žvèrių poveikio palankesnès sąlygos susidaro ir nitrofilinèms rūšims (Urtica dioica, Galeposis sp., Chelidonum majus) (Putman et al., 1989; Grime et at., 2007; Chytry, Danihelka, 1993). Pomiškio ir trako eliminavimas kai kurioms žolių rūšims (pvz., Angelica sylvestris, Filipendula ulmaria) taip pat sudaro palankesnes plitimo sąlygas (Grime et al., 2007).

\section{IŠVADOS}

1. Laikant danielius aptvare per septynerius metus sumažèjo:

- pomiškio ir trako vidutinè projekcinè danga;

- Alnus incana, Picea abies ir Sorbus aucuparia medelių;

- žolinès dangos projekcinè danga;

- Calamagrostis arundinacea, Carex digitata, Deschampsia cespitosa, Oxalis acetosella, Maianthemum bifolium, Mycelis muralis, Rubus idaeus vidutinè projekcinè danga;

- samanų dangos projekcinè danga per nagrinèjamą laikotarpi padidejjo.

2. Laikant danielius aptvare stipriausiai ir greičiausiai jų poveikis išryškèjo pomiškiui bei trakui, šiek tiek mažiau žolinei dangai, mažiausia - samanoms.

3. Danielių poveikis labiausiai išryškëjo po $3-4$ metų, kai gyvūnų skaičius aptvare buvo didžiausias. Sumažèjus danielių, pirmiausiai pradejo atsistatyti žolinė danga, po trejų metų atsirado pomiškio ir trako medelių.
Gauta 20140121

Priimta 20140512

\section{LITERATŪRA}

1. Baines D., Sage R. B., Baines M. M. 1994. The implications of red deer grazing to ground vegetation and invertebrate community structure of Scottish native pinewoods. Journal of Applied Ecology. Vol. 31. P. 776-783.

2. Baleišis R., Bluzma P., Balčiauskas L. 2003. Lietuvos kanopiniai žvérys. Vilnius. $215 \mathrm{p}$.

3. Bradshaw R. H. W., Hannon G. E., Lister A. M. 2003. A long-term perspective on ungulate-vegetation interactions. Forest Ecology and Management. Vol. 181. P. 267-280.

4. Chytry M., Danihelka J. 1993. Long-term changes in the field layer of oak-hornbeam forests under the impact of deer and mouflon. Folia Geobotanica \& Phytotaxonomica. Vol. 28. P. 225-245.

5. Gill R. M. A. 1992. A review of damage by mammals in north temperate forests: Impact on trees and forests. Forestry. Vol. 65. P. 363-388.

6. Gill R. M. A., Beardal V. 2001. The impact of deer on woodlands: the effects of browsing and seed dispersal on vegetation structure and composition. Forestry. Vol. 74. No. 3. P. 210-218.

7. Grime J. P., Hodson J. G., Hunt R. 2007. Comparative Plant Ecology. London: Castlepoint Press. $748 \mathrm{p}$.

8. Gudžinskas Z. 1999. Lietuvos induočiai augalai. Vilnius: Botanikos instituto leidykla. 211 p.

9. Hobbs N. T. 1996. Modification of ecosystems by ungulates. Journal of Wildlife Management. Vol. 60. P. 695-713.

10. Joys A. C., Fuller R. J., Dolman P. M. 2004. Influences of deer browsing, coppice history, and standard trees on the growth and development of vegetation structure in coppiced woods in lowland England. Forest Ecology and Management. Vol. 202. P. 23-37.

11. Kirby K. J. 2001. The impact of deer on the ground flora of British broadleaved woodland. Forestry. Vol. 74. No. 3. P. 219-229.

12. Marozas V., Pètelis K., Brazaitis G., Baranauskaitè J. 2009. Early changes of ground vegetation in fallow deer enclosure. Baltic Forestry. Vol. 15. No 2. P. 268-272.

13. Miller S. G., Bratton S. P., Hadidan J. 1992. Impacts of whitetailed deer on endangered plants. Natural Areas Journal. Vol. 12. P. 67-74.

14. Morecroft M. D., Taylor M. E., Ellwood S. A., Quinn S. A. 2001. Impacts of deer herbivory on ground vegetation at Wytham Woods, central England. Forestry. Vol. 74. No. 3. P. 251-257.

15. Motta R. 2003. Ungulate impact on rowan and Norway spruce height structure in mountain 
forests in the eastern Italian Alps. Forest Ecology and Management. Vol. 181. P. 139-150.

16. Pètelis K. 1998. Danielių aklimatizacijos problemos ir perspektyvos Lietuvoje. In: Mišku ükio ir aplinkos apsaugos problemos: mokslinès konferencijos medžiaga. Kaunas: Akademija. P. 87-89.

17. Pètelis K. 2002. Reaklimatizuotu bei aklimatizuoty kanopiniu žveriu populiaciju formavimasis ir kokybe Pietvakariu Lietuvos miškuose: daktaro disertacijos santrauka. Akademija. $26 \mathrm{p}$.

18. Petelis K. 2004. Fallow deer acclimatization in Lithuania. Rational Management of Cervids in Forest Habitats: Proceedings of the International Symposium. $112 \mathrm{p}$.

19. Pètelis K. 2010. Danieliu aklimatizacija Lietuvoje. Medžiokle [žiūrèta 2014-01-18]. Prieiga per internetą: http://www.medziokle.info/gyvnija/607-danieli-aklimatizacoja-lietuvoje/

20. Pètelis K., Baranauskaitė J., Gečas R. 2010. Danielių aklimatizacija Šilutes miškų urèdijoje. Žmogaus ir gamtos sauga 2010: tarptautinès mokslinès-praktinès konferencijos medžiaga. D. 2. P. 29-32.

21. Pigott C. D. 1983. Regeneration of an oak-birch woodland following exclusion of ships. Journal of Ecology. Vol. 71. P. 629-646.

22. Putman R. J., Edwards P. J., Mann J. C. E., How R. C., Hill S. D. 1989. Vegetation and faunal changes in an area of heavily grazed woodland following relief of grazing. Biology Conservation. Vol. 47. P. 13-32.

23. Rooney T. P. 2001. Deer impacts on forest ecosystems: a North American perspective. Forestry. Vol. 74. No. 3. P. 201-208.

24. Rooney T. P., Dress W. J. 1997. Species loss over sixty-six years in the ground layer vegetation of Heart's Content, an old-growth forest in Pennsylvania USA. Natural Areas Journal. Vol. 17. P. 297-305.

25. Rooney T. R., Waller M. D. 2003. Direct and indirect effects of white-tailed deer in forest ecosystems. Forest Ecology and Management. Vol. 181. P. 65-176.

26. Ruzicka K. J., Groninger J. W., Zaczek J. J. 2010. Deer browsing, forest edge effects, and vegetation dynamics following bottomland forest restoration. Restoration Ecology. Vol. 18. P. 702-710.
Vitas Marozas, Jurgita Baranauskaitė, Kęstutis Pètelis

\section{EFFECT OF FALLOW DEER HELD IN} AN ENCLOSURE ON SAPLINGS, UNDERGROWTH, HERBS AND MOSS LAYERS

\section{Summary}

The aim of the study was to evaluate the impact of fallow deer, held in an enclosure, on forest vegetation: saplings, undergrowth, herbs layers and mosses. The study was accomplished in the enclosure of Mikieriai forest district of Anykščiai forest enterprise in 2005-2012. Two permanent plots were selected - a spruce stand with birch $20 \mathrm{~m}$ from the feeder and a spruce stand in the middle of the enclosure. An area of the plot was $100 \mathrm{~m}^{2}$. Each sample plot was divided into 25 subplots $\left(2 \times 2 \mathrm{~m}^{2}\right.$ area $)$. In these subplots we counted undergrowth tree saplings and shrubs. The species composition and percentage of the projection cover for each species of dwarf shrubs, herbaceous plants and mosses were determined. Results showed that during the seven years the average projection cover of undergrowth, shrubs, herbs and dwarf shrubs decreased. The amount of Alnus incana, Picea abies and Sorbus aucuparia species decreased. The average projection cover of Calamagrostis arundinacea, Carex digitata, Deschampsia cespitosa, Oxalis acetosella, Maianthemum bifolium and Rubus idaeus decreased as well. The average projection cover of mosses increased. The most intensive impact of fallow deer was on saplings and undergrowth, less effect was on herbs and the least impact was on mosses. The impact of fallow deer was most intensive after 3-4 years when the amount of animals was the largest. When the amount of fallow deer decreased, the herbs started to recover first, and then saplings and undergrowth appeared.

Key words: cervines, herbs, mosses, projection cover, undulate 